\title{
INCLUSIVE BUSINESS MODELS IN COFFEE VALUE CHAIN: COMPARING PRACTICAL EVIDENCE BETWEEN EAST JAVA AND NORTH SUMATERA
}

\author{
Heti Mulyati*)1, Dikky Indrawan ${ }^{* *}$ \\ *Department of Management, Faculty of Economics and Management, IPB University \\ Jl. Agatis, Campus of IPB Darmaga Bogor 16680, Indonesia \\ ${ }^{* *}$ School of Business, IPB University \\ Jl. Pajajaran Bogor 16151, Indonesia
}

\begin{abstract}
This paper explores inclusive business practices by focusing on the relationship between investments for-profit and social impact for small-scale farmers. Value chain mapping was used and combined with business model canvas to enable fact-finding and linkage between profit-taking action and social impact in the coffee value chain. The study was performed in two regions: East Java and North Sumatra. The study interviewed 72 farmers from Bondowoso District, East Java, and 30 farmers from Mandailing Natal District, North Sumatra. The qualitative analysis revealed the role of local organization networks in supporting the extension and improving performance in value chain governance. The organization networks supported social issues and provided access to diverse resources and environments for companies to build commitments. Furthermore, the business model canvas modeled value propositions that were practically tackling the dimensions of profit and social impact to the organization's context. The coffee value chains in both regions were differ based on key features and elements of small farmers' inclusion in the coffee value chain. The findings show that the coffee business model in Mandailing Natal encouraged smallholder farmer inclusion better than in Bondowoso. Therefore, the study implies that a shifting from profit into social initiatives in inclusive business is needed. This study provides practical evidence of business model canvas in the coffee value chain cases, showing how to develop a mission social innovation in a profit organization.
\end{abstract}

Keywords: inclusive business models, business model canvas, value chain, coffee

\begin{abstract}
Abstrak: Penelitian ini mempelajari praktik bisnis inklusif yang berfokus pada hubungan antara investasi untuk keuntungan dan investasi untuk dampak sosial bagi petani skala kecil. Metode yang digunakan adalah pemetaan rantai nilai yang dikombinasikan dengan kanvas model bisnis untuk mencari fakta dan menghubungkan antara aksi perusahaan dalam mengambil keuntungan dan memberikan dampak sosial dalam rantai nilai kopi. Penelitian dilakukan di dua wilayah yaitu Jawa Timur dan Sumatera Utara. Penelitian ini mewawancarai 72 petani dari Kabupaten Bondowoso, Jawa Timur, dan 30 petani dari Kabupaten Mandailing Natal, Sumatera Utara. Hasil analisis kualitatif mengungkapkan peran jaringan organisasi lokal dalam mendukung penyuluhan dan peningkatan kinerja tata kelola rantai nilai kopi. Jaringan organisasi mendukung isu-isu sosial dan menyediakan akses ke berbagai sumber daya dan lingkungan bagi perusahaan untuk membangun komitmen bersama. Selanjutnya, kanvas model bisnis memberikan model dengan proposisi nilai terhadap konteks organisasi yang secara praktis menangani dimensi keuntungan dan dampak sosial. Hasil analisis juga menunjukkan bahwa rantai nilai kopi di kedua wilayah berbeda berdasarkan fitur utama dan elemen yang melibatkan petani kecil dalam rantai nilai kopi. Hasil tersebut menunjukkan bahwa model bisnis kopi di Mandailing Natal lebih mampu mendorong inklusi petani kecil dalam rantai nilai kopi dibandingkan model bisnis di Bondowoso. Kesimpulannya, studi ini menunjukkan bahwa pergeseran dari keuntungan menjadi inisiatif sosial dalam bisnis inklusif sangat diperlukan. Studi ini membuktikan bahwa penggunaan kanvas model bisnis dalam kasus rantai nilai kopi, mampu menunjukkan proses pengembangan misi inovasi sosial dalam organisasi laba.
\end{abstract}

Kata kunci: model bisnis inklusif, kanvas model bisnis, rantai nilai, kopi

${ }^{1}$ Corresponding author:

Email: heti@apps.ipb.ac.id 


\section{INTRODUCTION}

In 2017, Indonesia was the world's fourth-largest coffee exporter, trailing only Brazil, Vietnam, and Colombia. The main market in the supply of Indonesian coffee products is the export market. The export market serves by various specialty coffees, cultivated from Arabica dan Robusta, are produced by farmers in different locations such as Bali, Flores, Gayo, and Toraja, in Indonesia. (Belachew et al. 2015; Sedana and Astawa, 2016; Fadhil et al. 2018; Fadhil et al. 2019). The harvesting and processing processes used by farmers have a significant impact on the taste of each coffee, which becomes its strength and uniqueness (Aknesia et al.2015; Sedana and Astawa, 2019).

Coffee cultivation management in Indonesia is not effective and efficient; hence farmers earn a smallmargin. Low productivity, poor product quality, low pricing, and limited access to information, technology, and the market are all contributing factors to the ineffectiveness and inefficiency (Dowdall, 2012; Gathura, 2013; Minh et al. 2016; Mapiemfu-Lamaré et al. 2017). Moreover, smallholder farmers have limited connections with commercial actors like buyers, exporters, and others. While state development funds have been reduced as a result of free market reforms, governments have increasingly turned to the private sector to attract new investment into rural areas. The government intention is aligned with the inclusive business paradigm, which was part of The Sustainable Development Goals (SDGs) proposed by the United Nations. Governments, NGOs, donors, and big agri-food corporations have all enthusiastically adopted "inclusive business" as a crucial term structuring efforts to improve the compatibility between agribusiness expansion and rural livelihoods (Chamberlain and Anseeuw, 2019; German et al. 2018; SNV and WBCSD, 2008; Vorley and Proctor, 2008; Woodhill, 2016). Therefore, the coffee farmers should take the opportunity and be connected with the private sectors to enhance their coffee businesses.

Currently, many businesses continue to innovate their business models to achieve SDGs to fulfill their mission after implementing inclusiveness in the Agrivalue chain in the 1990s. In the Agri-value chain, the companies seek inclusive businesses by balancing profit-making and social effects. In general, inclusive business models offer small-scale farmers opportunities for market inclusion while adhering to value chain governance. Farmers in Indonesia's coffee value chain are included in this SDGs incentive. Lessons learned from inclusive business projects involving smallholder farmers have revealed that farmer participation in the business could increase the added value, productivity, and quality of coffee produced by farmers (Sedana and Astawa, 2019).

A variety of inclusive business practices exists in Indonesian coffee farming. Common practices show that inclusive business has been modified to reflect the wide range of experiences that exist across business models. Differences in practices are demonstrating a variety of contract terms, ownership structures, and leadership impact depending on household characteristics, land uses, and livelihoods (Scoones et al. 2018; Vicol et al. 2018). Hence, inclusive business in Indonesian coffee businesses indicates full of ambiguity and specificity across homes, business models, and geographies. Various forms of social inclusion and exclusion are dependent (Sedana and Astawa, 2019). We aim to identify structural factors shaping the boundaries of possibility both within and across value chains by selecting a set of value chains for their diversity and reviewing the implications of major trends for inclusiveness. This paper explores the practices of inclusive business of Indonesian coffee business by focusing on the relationship between investments forprofit and social impact for small-scale farmers. This research contributes to the existing literatures and the findings will be useful for better application of inclusive business in the coffee value chain.

\section{METHODS}

The study was designed as a desk study which was conducted as a follow-up study from Lubis (2017) and Permatasari (2018). These studies were performed at arabica coffee business in two regions: Bondowoso District, East Java, and Mandailing Natal District, North Sumatra. ondowoso District, East Java, is known as the largest regional coffee supplier to the export market in East Java Province. Mandailing Natal District, North Sumatra is known as the regional best quality and largest coffee supplier in North Sumatra province.

These studies carried out in-depth and semi-structured interviews with key-value chain stakeholders to assess the business model and inclusiveness practices in the different identified coffee value chains. The questionnaires were adapted from Gereffi et al. 
(2005) on the value chain and Lundy et al. (2014) on the capabilities in the inclusiveness based on link methodology. Each variable was following the previous studies from Williamson (2002), Kaplinsky and Morris, (2000), Gereffi et al. 2005), and Indrawan et al. (2018).

Two different sampling methods were applied. Respondents in Bondowoso District, East Java, were selected by using purposive sampling. Whereas respondents in Mandailing Natal District, North Sumatra, were selected by using stratified random sampling. The criteria for respondents were Arabica coffee farmers, members of cooperatives, owned and managed coffee plantations with a maximum land area of 2 (two) hectares. Sample size was determined from the farmers' population based on these criteria. The collected samples were 72 farmers from Bondowoso District, East Java, and 30 farmers from Mandailing Natal District, North Sumatra.

This study used a qualitative approach to process the collected data. The qualitative approach was designed to assess and compare inclusive business practices by following the link methodology, which was proven to be an effective strategic tool for developing business processes. The methods used to find a gap between farmers and modern markets, bridge the gap between smallholders, and develop a strategy for farmers to take advantage of market opportunities (Lundy et al. 2014). The link methodology's approaches were deployed to iteratively initiate, implement, and finish the participatory innovation process from the "designtest-check-act" cycle.

The data were processed in four stages. First, Mapping the coffee Value Chain. The value chain was mapped as a graphical representation of coffee business activity that follows value chain analysis methods (Kaplinsky and Morris, 2000). The value chain map consisted of internal business processes, partner networks, and external influences (Williamson, 2002; Gereffi et al. 2005; Indrawan et al. 2018). Second, drawing the Business Model Canvas. After mapping the coffee value chain, the canvas business model, which adapted from Osterwalder's (2004) approach, was developed to find the gap. The canvas illustrated a model to understand business objectives and practices in coffee businesses. In the coffee value chain, value chain mapping was used in conjunction with a business model canvas to enable fact-finding and the connection between profit-taking action and social impact. Third, the New Business Model Principles. In this stage, the study built the new business model that represents a set of evaluation guidelines in inclusivity and improvement on business inclusiveness based on the gap (Lundy et al. 2014; Kelly et al. 2015). Fourth, the Prototype cycles. In the final stage, the study developed a prototype that follows the prototype cycle. We designed, tested, and evaluated the progress of innovative programs on business models (Lundy et al. 2014). The developed prototype followed an iterative design-testing-evaluation process for improving specific aspects of the business model (Sopov et al. 2014).

The collected and processed data were analyzed in three stages as follows: First, we identified structural factors that set up the business environment in the coffee value chains. Second, we reviewed the major trends for inclusiveness in the structural factors involved in the value chain. Lastly, we analyzed the relationship between investments for-profit and social impact for small-scale farmers in the value chain. The assessment was made following the qualitative likelihood of the factors or activities that exist in the value chains. The ordinal scale measurement was used, which 1 is for the least likelihood, and 4 is for the highest likelihood. In the analyses, we converted the ordinal scale into a plus $(+)$ sign to illustrate the level of each indicator.

\section{RESULTS}

The findings in Bondowoso district and Mandailing Natal district revealed that inclusive business was influenced by the role of local organization networks in supporting the extension and improving performance in value chain governance. A complex value chain exists in both districts, and various stakeholders were involved in these chains. Many stakeholders are involved in these chains, starting from farmers, traders, local coffee shops, exporters, cooperatives, government, and non-government organizations. In the Bondowoso district, the value chain was driven by farmers via a cooperative. They were mostly involved with the Regional Government (Pemda) of Bondowoso District, the Association of Indonesian Coffee Farmers (APEKI), Perhutani, and the Coffee and Cocoa Research Center (Puslitkoka), Bank Indonesia (BI), Bank Jawa Timur (Jatim). These stakeholders provided training, tool assistance, direct guidance, and consultation for farmers in the Bondowoso district. The Mandailing Arabica 
coffee value chain stakeholders were the Mandailing Natal District Agriculture Office, Farmers Group, Sumatra Rainforest Institute, and the Mandailing Coffee Society Cares about Geographical Indications (MPGI). In this district, the actors had more collaboration and support for smallholder's improvement. Farmer groups had more roles, especially in building up a forum for sharing good farming and processing knowledge. This role was supported by the Sumatra Rainforest Institute who serves as an institution that guides novice farmers. This organization is in collaboration with the Mandailing Natal District Agriculture Office, and the Mandailing Coffee Care Society for Geographical Indications (MPGI) to solve the problems faced by small farmers. The collaboration was strengthening the Mandailing Natal District Agriculture Office role, which was to provide direct training and mentoring to coffee farmers. Both chains had traders and exporters as the market hub. However, the exporters in Mandailing Natal were in favor of supporting smallholders' role in the value chain.

There were many stakeholders involved in these chains with frequent contact and transactions. The trading in these chains involved many links in chain stages. These value chain links existed in both regions due to the fact that coffee business involved social relations in trading. It mostly due to coffee processing and handling to serve each market orientation. Therefore, these chain governances had a high number of transactions since coffee processing involved many actors with varied contact frequencies.

Even though these chains were similar, these chains had slightly different in the internal process, especially in the level of transaction complexity. The Bondowoso coffee value chain transactions were not simple and linear between chain levels since the possibilities of changing relationships were higher due to market orientation and rent-seeking behavior. The farmers often faced a lower price and depended on the cooperatives or traders to sell their coffee beans. Cooperatives provided a long-term contract for farmers to guarantee their market access. Farmers who were not a member of cooperatives dealt with many traders, which often for an on-spot transaction. The chain coordination was limited only to the cooperatives' members. Whereas, the transactions in the Mandailing Natal coffee value chain were less complicated due to the chain actors' effort in certifying their coffee for a better market. As they aimed in the export market, this chain was expected to increase farmers' ability and involvement in chain decision-making. Such efforts were a gradual process and took collaborative action. Therefore, this chain had better chain coordination. As expected, the internal process based on the modular governance in these chains resulted in a high ability to codify transactions. Therefore, in most cases, a variety of quality was sold in the market and coffee sortation performed based on market demand and requirement. However, the effort made by actors in the Mandailing Natal coffee value chain that aimed for better quality may have a better possibility in sustainable business.

As mentioned earlier, the study found that the external environment for both value chains was different (Table 1). It appears that the government involvement was higher in the Bondowoso value chain than in the Mandailing Natal value chain. Furthermore, the farmers' association and cooperatives had more influence in the coffee business in Bondowoso district than Mandailing Natal districts. Whereas, the non-governmental organization such as Rainforest Institute and Lembaga Masyarakat Peduli Indikasi Geografis had more influence in Mandailing Natal district than in Bondowoso district. The organization networks promoted social issues and gave businesses access to a variety of resources and environments to make commitments. As a result, the smallholder's involvement was found higher in the Mandailing Natal district. Since the community supported the farmers and other stallholders' actors, the supports were more valuable and preferred than the government. The government efforts were acknowledged but had small stimulation in the inclusiveness for smallholders. Therefore, the inclusive business practice was found better in the Mandailing Natal district.

Based on important aspects and elements of small farmers' inclusion in the coffee value chain, we found the differences between these business models for each value chain aimed at different goals (Table 2). The business model elements show that the Bondowoso coffee value chain served traders and exporters to sell all kinds of coffee beans. In contrast, the Mandailing Natal coffee value chain selected a more specific customer segment. The findings show that the inclusive business was determined by key activity, which the chain actors performed through the involvement of key partners. 
Table 1. The likelihood of structural factors influences on inclusive business in the coffee value chain governance Enabling Condition of Inclusive Bondowoso District, East Java Mandailing Natal District, North Business in the Chain Sumatra

Chain Governance

Modular

Modular

\section{Value chain stakeholders}

Number of Actors involved

Number of Contact frequencies

Number of links in Chain Stages

$$
\begin{gathered}
+++ \\
++++ \\
++++ \\
++ \\
+++ \\
++++ \\
+++
\end{gathered}
$$

\section{Internal Chain Process}

Degree of coordination

Capabilities in the supply base

Ability to codify transactions

Complexity of transactions$$
+++
$$$$
+++
$$

\section{External Chain Influence}

Government

Farmers associations

Banking Sectors

Cooperatives

Non-Government Organisation

(Consultants)

$$
\begin{gathered}
+++ \\
+++ \\
++ \\
+++ \\
+
\end{gathered}
$$

$$
\begin{gathered}
+++ \\
+++ \\
+++ \\
++ \\
\\
++ \\
++ \\
++ \\
++ \\
++++
\end{gathered}
$$

\begin{tabular}{|c|c|c|}
\hline Indicators & Bondowoso District, East Java & $\begin{array}{c}\text { Mandailing Natal District, North } \\
\text { Sumatra }\end{array}$ \\
\hline \multicolumn{3}{|l|}{ Business Model Elements } \\
\hline Customer segments & Traders and Exporters & Local Café and Exporters \\
\hline Value propositions & All quality Green beans & High quality and certified green beans \\
\hline Channels & Cooperative and non-cooperative market channels & Direct sales \\
\hline Customer relationships & Transactional & Salesman engagements \\
\hline Revenue streams & Green bean sales & Green bean sales \\
\hline Key resources & Farmers & Chain actors \\
\hline Key activities & Separated Roasting and Distribution & $\begin{array}{l}\text { Smallholders' inclusion in Roasting } \\
\text { and Distribution Decision }\end{array}$ \\
\hline Key partnerships & $\begin{array}{l}\text { With cooperative and farmers association } \\
\qquad(\mathrm{APEKI})\end{array}$ & $\begin{array}{l}\text { With external chain actor: Government } \\
\text { and non-governmental organization } \\
\text { (MPIG) }\end{array}$ \\
\hline Cost structure & Farm cost and investment & Chain cost and investment \\
\hline \multicolumn{3}{|c|}{ Trend of Inclusive Business } \\
\hline Profit initiatives & ++++ & ++++ \\
\hline Social Initiatives & + & +++ \\
\hline Environmental Initiatives & + & + \\
\hline Impact for smallholders & + & +++ \\
\hline
\end{tabular}

\section{Inclusive Business Practices}

Smallholders initiatives

Private Initiatives

$$
\begin{gathered}
+ \\
++ \\
++++
\end{gathered}
$$$$
+++
$$$$
+++
$$$$
++
$$

Non-Government Initiatives

$+$

$+++$

Note: $+=$ the least likelihood, $++++=$ the highest likelihood

Table 2. Comparison of the Business Model elements and inclusive business trend in the coffee value chain

Note: $+=$ the least likelihood, $++++=$ the highest likelihood 
The Bondowoso coffee value chain aimed to serve customers who preferred coffee quality over price. Consequently, the business model canvases were designed the value propositions that practically addressed the dimensions of profit and social effect to the organization's setting. The business model of Bondowoso coffee was focus on selling all types of quality as their value proposition via cooperatives as the main marketing channel. The cooperative acted as the marketing representative to the market. Thus, limited relations existed between farmers with the customers. Hence, the partnership only existed between farmers with cooperative and farmers' association. Cooperative and farmers' association (APEKI), as the main partner in the Bondowoso coffee value chain, had their focus on increasing the value-added. As results, the chain actors held responsible in managing their farm cost and investment to support productivity and sells more green beans. Therefore, this chain cost structure was based on individual cost and investment.

Whereas the business model of Mandailing Natal coffee was focus on high-quality and certified green beans. Subsequently, this chain had a direct marketing channel for their products. The marketing strategy revolved around sales engagement. The strategy has a higher level of customer relationship than the Bondowoso coffee value chain. The customer relationship via sales engagements enabled farmers' involvement in the value chain. The smallholders' inclusion in the Mandailing Natal coffee value chain was endorsed by external chain actors. The government and non-governmental organizations (MPGI) collaborated in enhancing the coffee business in this value chain. As a result, the study found that the smallholders in this chain were included in the transaction, especially in the decision-making of roasting quality and distribution to the customers as the chain's key activities. Therefore, the partnership within the chain actors involved external chain actors and focused on the chain cost and investment rather than an individual actor. So, the chain actors in the Mandailing Natal coordinated their cost and investment to achieve higher quality coffee and served export market. While, this inclusion was not found in the Bondowoso coffee value chain.

This study provides practical evidence of a business model canvas in the coffee value chain, showing how to develop a mission social innovation in a profit organization. The findings show that both coffee value chains integrated an economic profit in their business models. Thus, the business models aimed to enhance the coffee value chain activities to increase sales. From the business models, the study found social initiative only in the Mandailing Natal coffee value chain. The high involvement from external chain actors had an impact on these initiatives. In contrast, the value chain actors in Bondowoso coffee felt that the involvement of cooperatives was a form of social initiative. Therefore, the cooperatives acted as their social vehicle, without realizing that subconsciously the profit goal of cooperative had limited the inclusion of farmers. In both business models, environmental initiatives were taken very lightly by the chain actors. These findings in the Mandailing coffee value chain had a better impact on smallholder farmers than

\section{Managerial Implications}

Both coffee value chains were affected differently by the findings. The value chain approach provides a framework for upgrading related to actor behavior participation in inclusive business initiatives in each chain governance in terms of business models. According to the provided theory, chain governance can choose between four types of upgrading, including process upgrading, product upgrading, functional upgrading, and chain upgrading, based on their coordination mechanism (Gereffi et al. 2005). The process upgrading can be applied throughout the chain by improving coffee roasting process to avoid crosscontamination and meet the food safety regulations. The product upgrading can be achieved by developing a new coffee product for the export market. Extended actor activity can set up functional upgrading to take one or more chain stages in their coordination mechanism. The final type of upgrading is chain upgrading, which involves moving to another related industry. The appropriate upgrade will be determined by the type of chain governance that needs to be improved. As the findings show that the value chain approach provides information about actors' relative influence on others' decision-making, we propose that the upgrading should increase an incentive to support inclusive business practices. Diverse goals in chain governance could be scaled up by combining a set of comprehensive chain upgrades that balance the goals of chain actors. 
The current inclusive business practice in the Bondowoso coffee value chain is limited to economic profit activities, with no consideration given to the interaction of actors in the value chain in order to increase farmer participation. As a result, developing a strategy for smallholder farmer inclusion should be done in such a way that it aims at value chain upgrading for the export market. In this value chain, process upgrading, product upgrading, and functional upgrading are all suggested. The main task at hand is to raise awareness of social initiatives throughout the Bondowoso coffee value chain. It should create incentives for chain actors to shift from a profit-oriented to a social-oriented mindset. When designing and carrying out upgrades to improve inclusive business practices, the chain actors should be involved (Permatasari et al. 2018). It is preferable if chain actors, particularly chain leaders, join the government's efforts voluntarily, aided by incentive mechanisms in the long run. The action strategy should involve farmers in the cooperative by focusing on their incentives to participate actively in value chain upgrading (Slamet et al. 2020). Coordination between farmers and cooperatives is expected to improve control as well as raise awareness among chain actors that the coffee business, as a global value chain, requires better inclusion of chain actors.

On the other hand, the Mandailing Natal coffee value chain could significantly improve its chain by changing the incentives for smallholder inclusion. Improving chain coordination in the global value chain also helps to bring incentives to encourage chain actors to participate in social and environmental initiatives. Furthermore, proper value chain upgrading analyses of improved business models are required. The inclusion of global partnership standards should be considered in the business model (Fadillah et al. 2019). Functional upgrading is suggested in this value chain for improved chain coordination mechanisms. Chain upgrading has the advantage of increasing not only inclusive business practices, but also inclusive development in the chain governance (Pouw and Gupta, 2017). The distribution of roles and responsibilities among actors in the value chain government should be considered. The enforcement of regulations is a final issue concerning measures to increase inclusive business in a specific direction (Likoko and Kini, 2017). When it comes to moving beyond voluntary behavioral changes, regulation enforcement is critical. Another way to raise awareness among chain actors is to run campaigns such as education and advertising for inclusive businesses.
As a consequence, in order for both coffee value chains to compete in the global market, the chain actors must first understand the food system and the export consumers' demand for inclusive business practices in order to develop a strategy (Fadillah et al. 2019; Indrawan and Daryanto, 2020). Furthermore, different types of farm business should be considered for a better strategy in improving food safety practice in the chain governance (Indrawan et al. 2020). This means that the strategy must be developed based on knowledge of the food system, a complex requirement in order to enter the international market. In the future, the development of an IoT business model for food safety should be included in the development of coffee value chain to ensure traceability and market assurance (Fadillah and Indrawan, 2020; Hasanah and Indrawan, 2020).

These findings show that both inclusive business practice in coffee value chain are in agreement with previous studies. The inclusive business practices are built based on the economic consequences as the main goal (Ros-Tonen, et al. 2019). Nevertheless, the practice in the coffee value chain Mandailing Natal is slightly moving forward following the trend of inclusive development mentioned by Pouw and Gupta (2017). This movement toward inclusive development is trying to fit in businesses, consumers, and civil society, which is in agreement with study by Likoko and Kini (2017). Furthermore, in the context of value chain governance, the value chain upgrading is found to be an important aspect that could stimulate farmer inclusion in the global value chain. The value chain upgrading such as food control and biosecurity could protect the producers in the global market, which is supported the study mentioned by Indrawan and Daryanto (2020).

\section{CONCLUSIONS AND RECOMMENDATIONS}

\section{Conclusions}

The study identified modular governance as the main structural factor that shaping the boundaries of coffee value chain in Bondowoso and Mandailing Natal. This modular governance provided a possibility for inclusive business diversity in practices. The comparison between Bondowoso and Mandailing Natal value chain indicated that the Bondowoso coffee value chain still focused on a profit-oriented business model. At the same time, the study found a combination of profit and social-oriented business models in the Mandailing Natal coffee value 
chain. It implies that major trends for inclusiveness are still based on profit with tendencies in social initiatives. Hence, the study indicates that inclusive business practices depended on the business model, which defines the relationship between investments for-profit and social impact for small-scale farmers.

\section{Recommendations}

We have created a large body of knowledge due to our work, which will be useful in designing future inclusive businesses in Indonesia. However, some details are still unknown. We primarily worked to gain a better understanding of coffee chain governance and were able to draw general business model conclusions. However, we did not investigate the mechanism of incentives or how these incentives might influence actors' motivation to change their behavior in upgrading the coffee value chain toward inclusive business and inclusive development. As a result, further research into the incentive mechanism in relation to principal-agent theory and agent-based models will be beneficial in future business studies on an inclusive business topic.

\section{REFERENCES}

Aknesia V, Daryanto A, Kirbrandoko K. 2015. Business development strategy for specialty coffee. Indonesian Journal of Business and Entrepreneurship 1(1):12-22. https://doi. org/10.17358/IJBE.1.1.12.

Belachew K, Teferi D, Gidisa G. 2015. Screening of some coffee arabica genotypes against coffee wilt diseases (Gibberella Xylarioides Heim and Saccus) at Jimma, Southwest Ethiopia. International Journal of Sustainable Agricultural Research 2(3):66-76. https://doi.org/10.18488/ journal.70/2015.2.3/70.3.66.76.

Chamberlain W, Anseeuw W. 2019 Inclusive businesses in agriculture: defining the concept and its complex and evolving partnership structures in the field. Land Use Policy 83:308-322. https:// doi.org/10.1016/j.landusepol.2019.02.008.

Dowdall C. 2012. Small farmer market knowledge and specialty coffee commodity chains in Western Highlands Guatemala [disertation]. Florida: Florida International University.

Fadhil R, Maarif MS, Bantacut T, Hermawan A. 2018. Situational analysis and intervention strategy for Gayo coffee agroindustry institution in Indonesia.
Journal of Food, Agriculture, and Environment 16(1):31-40.

Fadillah A, Indrawan D, Achsani NA. 2019. Indonesian coffee in the global value chain: The comparison of global partnership sustainability standards implementation. Jurnal Manajemen and Agribisnis 16(2):191-191.https://doi. org/10.17358/jma.16.2.191.

Fadillah A, Indrawan D. 2020. IoT Business Model Development for Food Safety Monitoring System in the Poultry Slaughterhouse. Di dalam: Materials Science and Engineering. Prosiding IOP Conference Series. hlm 12-22. https://doi. org/10.1088/1757-899X/874/1/012022.

Gathura MN. 2013. Factors affecting small-scale coffee production in Githunguri district, Kenya. International Journal of Academic Research in Business and Social Sciences 3(9):132-149. https://doi.org/10.6007/IJARBSS/v3-i9/195.

Gereffi G, Humphrey J, Sturgeon T. 2005. The governance of global value chains. Review of International Political Economy 12(1):78-104. https://doi.org/10.1080/09692290500049805.

German L, Cotula L, Gibson K, Locke A, Bonanno A, Quan J. 2018. Land Governance and Inclusive Business In Agriculture: Advancing The Debate. London: Overseas Development Institute.

Hasanah N, Indrawan, D. 2020. Food Safety Monitoring System using IoT in the Poultry Slaughterhouse. Di dalam: Earth and Environmental Science. Prosiding IOP Conference Series. hlm 12-43. https://doi.org/10.1088/17551315/519/1/012043.

Indrawan $\mathrm{D}$, Rich $\mathrm{KM}$, van Horne $\mathrm{P}$, Daryanto $\mathrm{A}$, Hogeveen H. 2018. Linking supply chain governance and biosecurity in the context of HPAI control in Western Java: A value chain perspective. Frontiers In Veterinary Science 5(2018): 94. https://doi.org/10.3389/ fvets.2018.00094.

Indrawan D, Cahyadi ER, Daryanto A, Hogeveen H. 2020. The role of farm business type on biosecurity practices in West Java broiler farms. Preventive Veterinary Medicine 176: 1-9. https:// doi.org/10.1016/j.prevetmed.2020.104910.

Indrawan D, Daryanto A. 2020. Food Control And Biosecurity Roles In The Global Value Chain: Supporting Producers or Safeguarding Consumers?. Di dalam: Earth and Environmental Science. Prosiding IOP Conference Series. hlm 12-40. https://doi.org/10.1088/1755- 
1315/519/1/012040.

Kaplinsky R, Morris M. 2000. A Handbook for Value Chain. Brighton: Institute of Development Studies, University of Sussex.

Kelly S, Vergara N, Bammann H. 2015. Inclusive Business Models. Rome: Food and Agriculture Organization of the United Nations.

Likoko E, Kini J. 2017. Inclusive business a business approach to development. Current Opinion in Environmental Sustainability 24:84-88. https:// doi.org/10.1016/j.cosust.2017.03.001.

Lubis N. 2017. Model bisnis inklusif kopi arabika Mandailing dan strategi pengembangannya di Kabupaten Mandailing Natal Sumatera Utara [skripsi]. Bogor: IPB University.

Lundy M, Amrein A, Hurtado Bermúdez JJ, Becx G, Zamierowski N, Rodriguez F, Mosquera EEE. 2014. LINK Methodology: A Participatory Guide To Business Models That Link Smallholders To Markets. Ed. ke-2.

Mapiemfu-Lamaré D, Ngome AF, Eyenga EF, Mbassi JEG, Suh C. 2017. Harvesting date influences cassava (Manihot Esculenta Crantz) yield and quality of based-products. Current Research in Agricultural Sciences 4(3):75-83. https://doi. org/10.18488/journal.68.2017.43.75.83.

Minh HT, Trang DTN, Chen JC. 2016. Input factors to sustainable development of coffee production in the Dak Lak province. Scientific Research 3(12):1-10.

Permatasari PC. 2018. Model bisnis inklusif untuk menduung kelangsungan usaha petani: Studi kasus rantai nilai kopi arabika Jawa Timur Indonesia [tesis]. Bogor: Sekolah Program Pascasarjana, IPB University.

PermatasariPC, BasithA, Mulyati H. 2018. Model bisnis inklusif rantai nilai kopi arabika di Bondowoso Jawa Timur. Jurnal Manajemen Teknologi 17(2):111-125.https://doi.org/10.12695/ jmt.2018.17.2.3.

Pouw N, Gupta J. 2017. Inclusive development: A multi-disciplinary approach. Current Opinion In Environmental Sustainability 24:104-108.

Ros-Tonen MA, Bitzer V, Laven A, de Leth DO, Van Leynseele Y, Vos A. 2019. Conceptualizing inclusiveness of smallholder value chain integration. Current Opinion in Environmental Sustainability 41:10-17.
Scoones I, Mavedzenge B, Murimbarimba F, Sukume C. 2018. Tobacco, contract farming, and agrarian change in Zimbabwe. Journal of Agrarian Change 18(1):22-42.

Sedana G, Astawa ND. 2016. Panca datu partnership in support of inclusive business for coffee development: the case of ngada district, province of Nusa Tenggara Timur Indonesia. Asian Journal of Agriculture and Development 13(2):75-98.

Sedana G, Astawa ND. 2019. Establishment of inclusive business on coffee production in Bali province: lesson from the coffee development project in Nusa Tenggara Timur province Indonesia. Asian Journal of Agriculture and Rural Development 9(1):111-122.

Slamet AS, Hadiguna RA, Mulyati H. 2020. Making food supply chain sustainable: participating smallholder farmers in modern retail channels. International Journal of Sustainable Agricultural Management and Informatics 6(2):135-162. https://doi.org/10.1504/IJSAMI.2020.108361.

SNV, WBCSD. 2008. Inclusive Business: Profitable Business For Successful Development. Geneva: WBCSD dan SNV.

Sopov M, Lundy M, Even B, Huong PT. 2016. Inclusive Business Models Toolkit: Link Methodology (abridged version). Cali: International Center for Tropical Agriculture (CIAT); Research Program on Policies, Institutions, and Markets (PIM); Wageningen University Research (WUR).

Vicol M, Neilson J, Hartatri DFS, Cooper P. 2018. Upgrading for whom? Relationship coffee, value chain interventions and rural development in Indonesia. World Development 110: 26-37. https://doi.org/10.1016/j.worlddev.2018.05.020.

Vorley B, Proctor F. 2008. Small-scale producer in modern agrifood markets. Restructuring market relations in food and agriculture in Central and Eastern Europe: impacts upon small farmers:2127.

Vorley B, Proctor F. 2008. Inclusive Business In Agrifood Markets: Evidence And Action. In Prosiding International Conference. Beijing.

Williamson OE. 2002. The theory of the firm as governance structure: from choice to contract. Journal of Economic Perspectives 16(3):171-95. https://doi.org/10.1257/089533002760278776.

Woodhill J. 2016. Inclusive Agribusiness: The State Of Play Background Working Paper. Rome:Global Donal Platform for Rural Development. 